\title{
Estimation of Methane Emission from Kossihouen Sanitary Landfill and Its Electricity Generation Potential (Côte d'Ivoire)
}

\author{
Kouakou Adjoumani Rodrigue ${ }^{1 *}$, Kra Essi ${ }^{2}$, Kouadio Marc Cyril $^{1}$, Trokourey Albert ${ }^{1}$ \\ ${ }^{1}$ Laboratoire de Chimie Physique, Université Félix Houphouët-Boigny, Abidjan, Côte d'Ivoire \\ ${ }^{2}$ Laboratoire de Mécanique et des Sciences des Matériaux, Institut National Polytechnique Felix Houphouët Boigny (INPHB), \\ Yamoussoukro, Côte d'Ivoire \\ Email: *adjoumanro@gmail.com
}

How to cite this paper: Adjoumani Rodrigue, K., Essi, K., Marc Cyril, K. and Albert, T. (2018) Estimation of Methane Emission from Kossihouen Sanitary Landfill and Its Electricity Generation Potential (Côte d'Ivoire). Journal of Power and Energy Engineering, 6, 22-31. https://doi.org/10.4236/jpee.2018.67002

Received: June 7, 2018

Accepted: July 9, 2018

Published: July 12, 2018

Copyright $\odot 2018$ by authors and Scientific Research Publishing Inc. This work is licensed under the Creative Commons Attribution International License (CC BY 4.0).

http://creativecommons.org/licenses/by/4.0/

\begin{abstract}
In order to solve the problem of the management of municipal solid waste in Abidjan (Côte d'Ivoire), a sanitary landfill has been designed in Kossihouen. Despite the adverse greenhouse effects of the methane, this gas has a potential of electrical energy. The estimation of methane emissions from the waste can be an economic and useful way for more accurate control and management of waste disposal in Kossihouen. Therefore, conducting this study is essential. Methane emissions were estimated based on the methane generation constant $\mathrm{K}$ and the methane generation potential $\mathrm{L}_{0}$ using LandGEM 3.02. The results show that the quantity of methane emissions was $7.97 \mathrm{E}+07 \mathrm{~m}^{3} /$ year. Based on this result, the methane content can generate $10 \%$ of total electricity consumed in Abidjan in 2026. This paper could serve as a source of scientific information for decision making on environmental sustainability in waste-to-energy projects in Côte d'Ivoire.
\end{abstract}

\section{Keywords}

Methane, LandGEM, Kossihouen, Landfill Gas

\section{Introduction}

Increasing growth of population and urbanization and subsequent development of industrial units have led to greater production of wastes and pollutants. The main environmental contaminants are Municipal Solid Wastes (MSW), million tons of which are daily produced worldwide [1]. The main disposal methods for municipal solid waste in West African countries are open dumping and sanitary 
landfill.

Landfills that are managed to minimize environmental impact and promote waste degradation can be integrated with technologies that include energy recovery systems. Many of the technologies that have been used to promote more sustainable landfills focus on the methods to foster waste treatment [2]. Sustainable landfill practices address how best to manage the landfill, including leachate and landfill gas (LFG). Landfills are usually considered to be anthropogenic sources of methane $\left(\mathrm{CH}_{4}\right)$, which has historically been the largest source of greenhouse gas (GHG) emissions from the waste sector [2]. Time dependent quantitative estimation of LFG production is the primary criterion that should determine the choice of method of gas utilization. Due to the difficulties in precisely monitoring methane emissions of whole landfill sites, modeling approaches are applied. These approaches include first-order decay (FOD), LFG generation models, including the US EPA's LFG emissions model (LandGEM), e-pollutants release and transfer registers (E-PRTR) (Fr) model, Intergovernmental Panel on Climate Change (IPCC) model, and Afvalzorg model [3]. One of the most commonly used and most flexible models is LandGEM [4]. This model that has been developed by the United States Environmental Protection Agency (USEPA), estimates an acceptable quantity of produced methane in landfills over time. It is governed by two main factors, the methane potential $\left(\mathrm{L}_{0}\right)$ and the decay rate (k) of landfill waste [5]. This model has been considered as an automatic estimation tool for modeling landfill methane emissions from municipal solid waste (MSW). It estimates the volume and composition of the generated methane throughout time because of the degradation of organic matter in the landfill. In addition, this model is an important step in developing a landfill project, which allows to estimate the available recoverable quantity of methane as fuel energy over time [4].

In the economic capital city of Cote d'Ivoire (Abidjan), the quantities of waste generated increased by about (3.75\%) between 2008 and 2014. This city is the largest MSW producer in the country. It produces about 3800 tons of solid waste a day. In Abidjan, MSW disposal has been a chronic problem [6]. In order to solve the problem of the MSW management, a sanitary landfill has been designed in Kossihouen. More recently, information on waste composition was improved, as this landfill categorize waste into that containing biodegradable and inert fraction. However, no data are available on component-specific methane yields. Because methane is both a potent greenhouse gas and a valuable low carbon fuel, improved predictability of landfill methane production is desirable. Modeling and predicting methane production and emission in landfills is very important in designing and exploiting such places [4]. This study aims to estimate methane emission from Kossihouen sanitary landfill using LandGEM (version 3.02) and to quantify its electricity generation potential. This study will provide a reliable database for decision makers for maximum exploitation of methane and its potential of energy. 


\section{Materials and Methods}

\subsection{Study Area}

Kossihouen is the first sanitary landfill in the autonomous district of Abidjan. It is located at the intersection of the North Highway and the unpaved road linking this village to Songon between latitudes $5^{\circ} 40$ and $5^{\circ} 30 \mathrm{~N}$ and longitudes $4^{\circ} 20$ and $4^{\circ} 10 \mathrm{~W}$ (Figure 1).

The Ivorian climate is tropical. The average annual temperature is $26.6^{\circ} \mathrm{C}$. Abidjan has an annual average rainfall of $1784 \mathrm{~mm}$ [7]. According to the 2014 Census, Abidjan had 4,707,000 people [8]. The total landfill site has an area of 3.3 ha, where $1,250,000$ tons (fresh matter) of municipal and commercial waste would be deposited [9]. Its capacity of storage is 7 years of operation. According to Waste Management Organization of Abidjan, the produced wastes would be deposited on this site, and the rest would be recycled or composted [9]. On the site, a layer of soil using ramp method as covered wastes [9]. In this study, methane emissions were estimated based on the assumption of a sanitary landfill that has been launched in 2018 and would be closed in 2025. The amount of generated waste was predicted basing on the population growth rate, the rate of waste generation per capita and its changes up to the plan horizon year (2025).

\subsection{LandGEM Data Analysis}

LandGEM is an automated tool for estimating emission rates for total landfill gas, methane, carbon dioxide. LandGEM can use either site-specific data to estimate emissions or default parameters if no site-specific data are available [5] [10]. LandGEM is based on a first-order decomposition rate equation for quantifying emissions from the decomposition of landfilled waste in MSW landfills. The model is presented to estimate annual emissions over a time period based on user specification [5] [11].

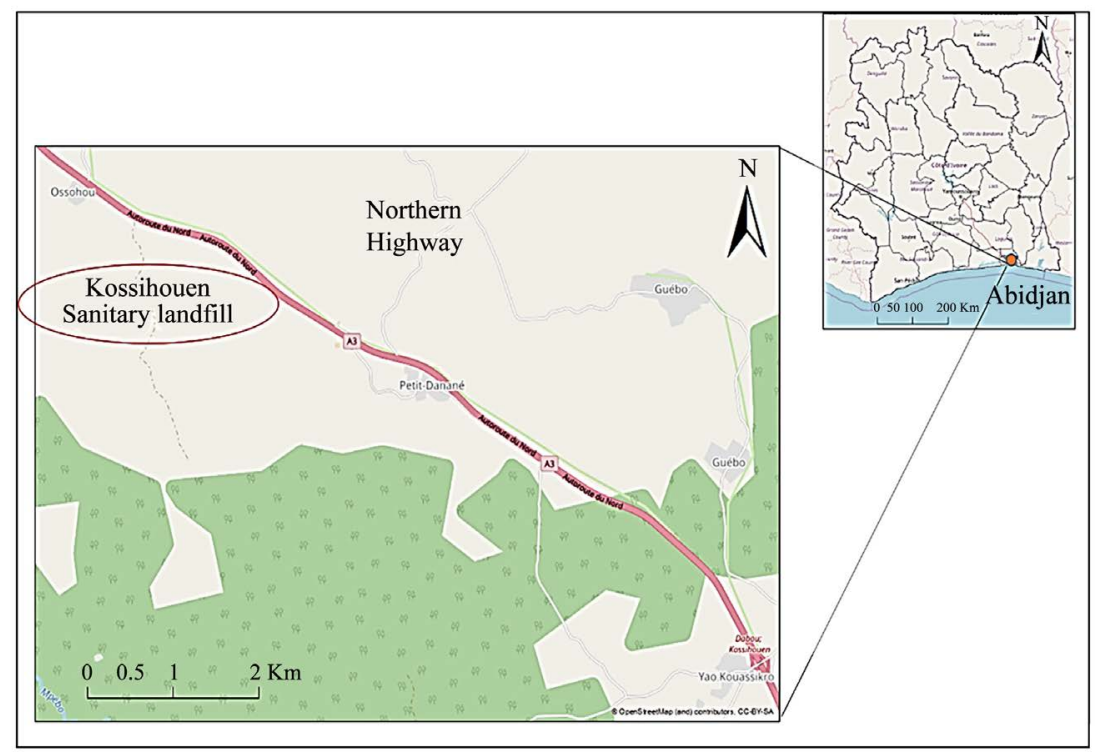

Figure 1. Location of Kossihouen landfill, Abidjan-Côte d'Ivoire. 
The LandGEM (version 3.02) emission methodology can be described mathematically using the following equation [5]:

$$
Q_{C H_{4}}=\sum_{i=1}^{n} \sum_{j=0,1}^{1} K L_{0}\left(\frac{M_{i}}{10}\right) \mathrm{e}^{-K t_{i j}}
$$

where: $Q_{\mathrm{CH}_{4}}=$ annual methane generation in the year of the calculation $\left(\mathrm{m}^{3} /\right.$ year $)$

$i=1$ year time increment,

$n=$ (year of the calculation) - (initial year of waste acceptance),

$j=0.1$ year time increment,

$K=$ methane generation rate (/year),

$L_{0}=$ potential methane generation capacity $\left(\mathrm{m}^{3} /\right.$ ton $)$,

$M_{i}=$ mass of waste accepted in the $i^{\text {th }}$ year (ton),

$t_{i j}=$ age of the $f^{\text {th }}$ section of waste mass Mi accepted in the $i^{\text {th }}$ year (decimal years, e.g., 3.2 years).

According to the equation, the required inputs for the amount estimation of generated methane are the design capacity of the landfill site, the annual acceptance rate, the methane generation constant $K$, the methane generation potential $L_{0}$ and the years of waste acceptance.

In Abidjan, only $65 \%$ of generated wastes are collected and transported to the landfill site [6]. Thus, Equation (1) was used to estimate the total quantity of the waste that would be deposited in Kossihouen landfill $\left(M_{F}\right)$ between 2019-2025 [12].

$$
M_{F}(t)=0.65 \times M_{T}
$$

$M_{T}$ (tons/yr) is the total mass of waste generated per year

$$
\begin{gathered}
M_{T}(t)=P(t) \times W_{C} \times 365 \\
P(t)=P_{0}(1+r)^{t}
\end{gathered}
$$

$P(t)$ is the expected population according to the population growth rate $(r)$ of $4.1 \%, W_{C}$ is the waste generation rate, which is of $0.77 \mathrm{~kg} / \mathrm{capita} /$ day [6].

The electrical energy (kWh/year) that could be obtained from the methane content of collected landfill gas is estimated as [12]:

$$
E_{P(\text { LFTGE })}=\frac{L H V_{\text {methane }} \times 0.9 \times Q_{C H 4} \times \lambda \times \eta}{3.6}
$$

where $\mathrm{LHV}_{\text {methane }}$ is the Lower Heating Value of methane and is given as 37.2 $\mathrm{MJ} / \mathrm{m}^{3}$ [6] [12], $\mathrm{Q}_{\mathrm{CH} 4}=$ annual methane generation in the year of the calculation ( $\mathrm{m}^{3} /$ year), 3.6 is the conversion factor from $\mathrm{MJ}$ to $\mathrm{kWh}$, where $\lambda$ is collection efficiency $(75 \%), \eta$ is the electrical conversion efficiency for internal combustion engine given as $33 \%$.

\section{Results and Discussion}

\subsection{Estimation of Methane Production}

Table 1 illustrates the population totals from 2018 to 2025 and the quantity of 
waste generated during the same period.

These results showed that the quantity of MSW increases with the growth of the population. The values of methane generation constant $(\mathrm{K})$ and the methane generation potential $\left(\mathrm{L}_{0}\right)$ have substantial effect on calculation of methane emission [13]. The value of methane generation constant (K) depends on the amount of waste moisture, $\mathrm{pH}$ and temperature, and nutrient availability for methanogenic bacteria [14]. Concerning the value of methane generation potential $\mathrm{L}_{0}$, it strongly depends on the fraction of the landfill waste [15]. According to USEPA guidelines, default values of $\mathrm{K}$ and $\mathrm{L}_{0}$ are $0.5 /$ year and $170 \mathrm{~m}^{3} /$ ton, respectively [5]. The determination of these parameters is based on the carbon content of the waste, biodegradable carbon, and a stoichiometric conversion factor [14]. If valid data is available on the quantity and quality of the waste, $\mathrm{L}_{0}$ was calculated, using several methods used in different references [14]. According to composition of the waste (Table 2) from Abidjan, the values of $\mathrm{K}$ and $\mathrm{L}_{0}$ were determined by Kouadio et al. [6]. Therefore, these values may be appropriate in estimating methane emission of Kossihouen landfill. In this study, default and determined values of $\mathrm{K}$ and $\mathrm{L}_{0}$ were be used to estimate methane emission. Table 3 and Table 4 show the description of the provided input data to run LandGEM (version 3.02). Based on LandGEM instruction, the estimated quantity of methane from landfill should be $50 \%$.

Table 5 shows the quantities solid waste that would be deposited in Kossihouen during 7 years of landfill open years. The deposited waste volume could be estimated to more than 1,000,000 tons during 2018-2020. This quantity could be increased during 2024-2025 to more than 1,300,000 tons. According to Table 5 , the total quantity of waste disposed at landfills would be 8,800,117 tons in 2025. This clearly indicates that the growth in MSW in Abidjan would outpace the population growth in future years.

Methane emission was estimated based on the methane generation constant $\mathrm{K}$ and the methane generation potential $\mathrm{L}_{0}$. Figure 2 presents the estimated of methane emission for default and determined values of $\mathrm{K}$ and $\mathrm{L}_{0}$.

Table 1. Population growth with $4.1 \%$ waste increase per year.

\begin{tabular}{ccc}
\hline Years & Population & Solid weight (ton/year) \\
\hline 2018 & $5,527,734$ & $1,553,570$ \\
2019 & $5,754,371$ & $1,617,266$ \\
2020 & $5,990,300$ & $1,683,574$ \\
2021 & $6,235,902$ & $1,752,600$ \\
2022 & $6,491,574$ & $1,824,457$ \\
2023 & $6,757,729$ & $1,899,260$ \\
2024 & $7,034,796$ & $1,977,129$ \\
2025 & $7,323,222$ & $2,058,192$ \\
\hline
\end{tabular}


Table 2. Annual average of the waste composition in Abidjan [6].

\begin{tabular}{cc}
\hline Composition of MSW & Percentage (\%) \\
\hline Putrescible & 45.42 \\
paper-cardboard & 14 \\
Leaf & 2 \\
Wood & 4 \\
Bone and straw & 3.42 \\
Textiles & 2.75 \\
Glass & 2.5 \\
Metals & 1.75 \\
Plastics & 8.5 \\
Stone & 1 \\
Battery & 1.41 \\
Sand, dust & 13.25 \\
\hline
\end{tabular}

Table 3. Description of the input data to run the LandGEM (default values of $\mathrm{K}$ and $\mathrm{L}_{0}$ ).

\begin{tabular}{cccc}
\hline \multicolumn{2}{c}{ Input Review } & Model Parameters \\
\hline Landfill Characteristics & Methane generation rate & $0.05 \mathrm{Year}^{-1}$ \\
Landfill open-closure year & $2018-2025$ & Potential methane generation & $170 \mathrm{~m}^{3} / \mathrm{t}$ \\
Gas pollutant selected & $(\mathrm{MW})$ & capacity & $\mathrm{ppmv}$ \\
Methane & 16.04 & NMOC concentration & $50 \%$ by volume \\
\hline
\end{tabular}

MW: Molecular weight for selected gases, Model parameters base on Clean Air (CAA) Regulations.

Table 4. Description of the input data to run the LandGEM (determined values of $\mathrm{K}$ and $\left.\mathrm{L}_{0}\right)$.

\begin{tabular}{|c|c|c|c|}
\hline Input Review & & & \\
\hline Landfill Characteristics & & Model Parameters & \\
\hline Landfill open-closure year & $2018-2025$ & Methane generation rate & 0.149 Year $^{-1}$ \\
\hline Gas pollutant selected & $(\mathrm{MW})$ & $\begin{array}{l}\text { Potential methane generation } \\
\text { capacity }\end{array}$ & $108 \mathrm{~m}^{3} / \mathrm{t}$ \\
\hline Methane & 16.04 & NMOC concentration & ppmv \\
\hline Carbon dioxide & 44.01 & Methane content & $50 \%$ by volume \\
\hline
\end{tabular}

Table 5. The quantity of disposed waste generated by municipal and industrial.

\begin{tabular}{ccccc}
\hline \multirow{2}{*}{ Year } & \multicolumn{2}{c}{ Waste Accepted } & \multicolumn{2}{c}{ Waste-in-Place } \\
\cline { 2 - 5 } & $($ tons/ year $)$ & $($ short tons/ year $)$ & $($ tons $)$ & (short tons) \\
\hline 2018 & $1,009,820$ & $1,110,802$ & 0 & 0 \\
2019 & $1,051,223$ & $1,156,345$ & $1,009,820$ & $1,110,802$ \\
\hline
\end{tabular}




\begin{tabular}{ccccc} 
Continued & \multicolumn{5}{l}{} \\
\hline 2020 & $1,094,323$ & $1,203,755$ & $2,061,043$ & $2,267,147$ \\
2021 & $1,139,190$ & $1,253,109$ & $3,155,366$ & $3,470,903$ \\
2022 & $1,185,897$ & $1,304,487$ & $4,294,556$ & $4,724,012$ \\
2023 & $1,234,519$ & $1,357,971$ & $5,480,453$ & $6,028,499$ \\
2024 & $1,285,134$ & $1,413,647$ & $6,714,972$ & $7,386,469$ \\
2025 & $1,337,825$ & $1,471,607$ & $8,000,106$ & $8,800,117$ \\
\hline
\end{tabular}

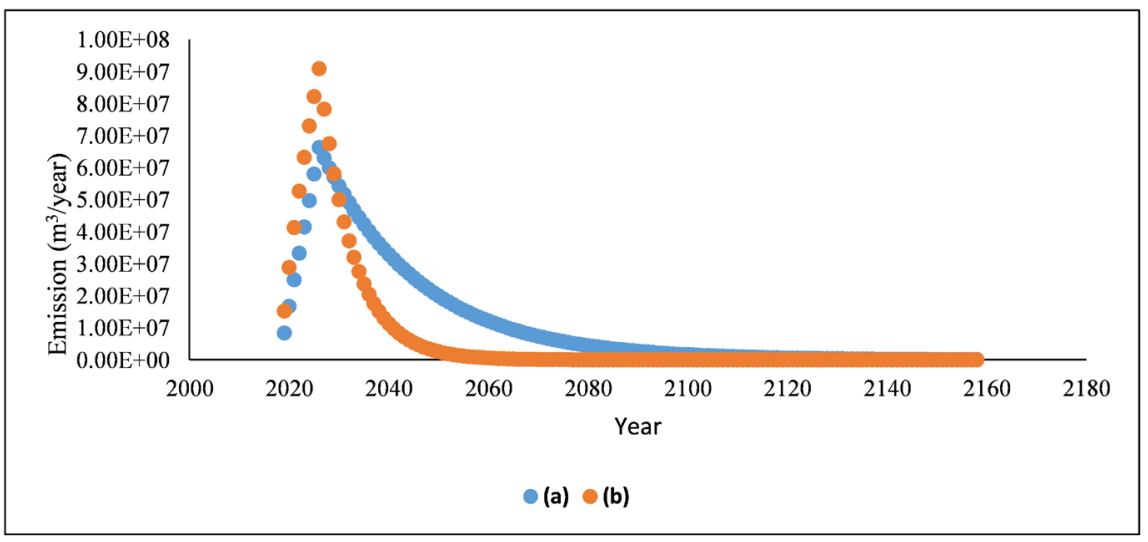

Figure 2. Estimate methane emission from Kossihouen landfill site from 2019 to 2160. (a): default values of $\mathrm{K}$ and $\mathrm{L}_{0}$ were be used to estimate methane emission; (b): determined values of $\mathrm{K}$ and $\mathrm{L}_{0}$ were be used to estimate methane emission.

The estimated quantities of methane would be the highest at least three years after the closure of landfill (2025-2028). The mean values were 7.97E+07 and $6.18 \mathrm{E}+07\left(\mathrm{~m}^{3} /\right.$ year $)$ for default and determined values of $\mathrm{K}$ and $\mathrm{L}_{0}$, respectively. However, the estimated quantities of methane for determined values of $\mathrm{K}$ and $\mathrm{L}_{0}$ are greater than those obtained using default values. The estimated quantities of methane gradually decrease until they reach zero. This trend is faster for determined values of $\mathrm{K}$ and $\mathrm{L}_{0}$. This could be explained by the fact that the effect of the half-life duration of organic materials such as food waste, paper, wood and textiles to the overall methane emission is related to the reaction rate $(\mathrm{k})$ of the model through the equation $k=t_{1 / 2}^{-1} \ln 2$ [16]. It is well known that paper and cardboard identified as an important compound, which could affect the methane emission [6]. According to waste composition (Table 2), paper and cardboard with approximately $14 \%$ contribute the large quantity of disposed materials. Half-life for paper estimated around 10 to 15 years, which could be a reason of maximum generation of methane during the years 2025 to 2028 [11]. Moreover, Food waste that ends up in landfills produces a large amount of methane [17]. Food waste contains approximately $45.42 \%$ in waste stream to this landfill (Table 2). Figure 3 shows the annually increasing of the methane emission from deposited waste in landfill. In fact, the degradation of MSW in tropical country such as Côte d'Ivoire may be higher due to higher temperature and moisture, which has positive effect on methane emission [11]. 


\subsection{Estimation of Electrical Energy Generation Potential}

In this section, the energy potential assessment of waste to energy from the treatment of MSW in from 2018-2035 is discussed. This assessment is based on the determined values of $\mathrm{K}$ and $\mathrm{L}_{0}$. The energy potential of Landfill Gas to Energy (LFGTE) technology depends largely on the methane content of the landfill gas generated, which in turn depends on the methane generation potential of the waste landfilled [12]. The electrical energy (GWh/year) that could be obtained from the methane content was given in Figure 4. The quantity of electric energy potentially would be available as from 2026 in the Kossihouen landfill would generate 209.15 GWh. In 2035, the recovered landfill methane would be sufficient to generate $54.61 \mathrm{GWh}$, providing a significant power generation opportunity. In fact, $209.15 \mathrm{GWh}$ would represent the $10 \%$ of total electricity consumed in Abidjan. This may be due to the fact that methane has basically the same chemical reactions as anaerobic digestion [12].

\section{Conclusion}

The methane emission has been estimated by using LandGEM model for Kossihouen sanitary landfill, Côte d'Ivoire. This landfill starts operation in 2018 with the purpose to receive the generated solid waste in Abidjan until the year

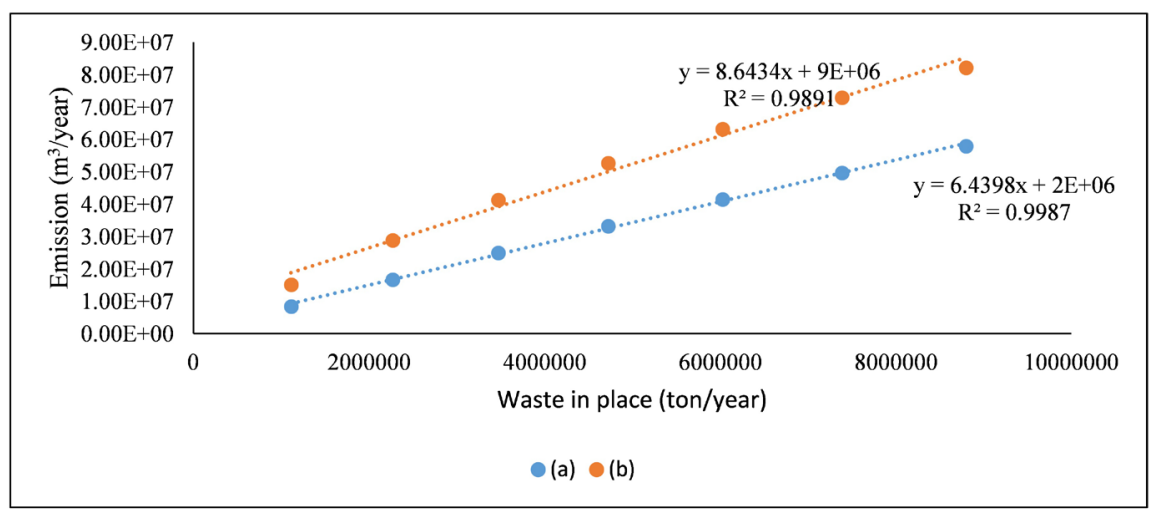

Figure 3. Annually increasing the methane production from disposed waste in landfill site from 2019 to 2025. (a): default values of $\mathrm{K}$ and $\mathrm{L}_{0}$ were be used to estimate methane emission; (b): determined values of $\mathrm{K}$ and $\mathrm{L}_{0}$ were be used to estimate methane emission.

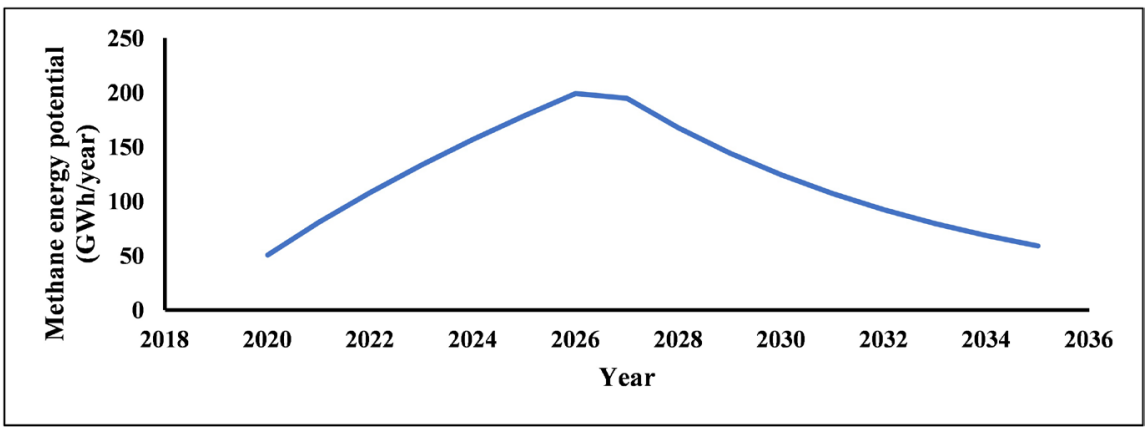

Figure 4. Energetic potential of methane in in landfill site. 
2025. The maximum methane generation rate occurred during the years 2025-2028. The peck of generation was 7.97E+07 and $6.18 \mathrm{E}+07\left(\mathrm{~m}^{3} /\right.$ year $)$ for default and determined values of $\mathrm{K}$ and $\mathrm{L}_{0}$, respectively. The intention of this paper is to demonstrate that, based on theoretical information presented above it can be assumed that the quantity of methane produced could be used to cover part of the electrical needs in Abidjan.

\section{References}

[1] Liu, A., et al. (2015) A Review of Municipal Solid Waste Environmental Standards with a Focus on Incinerator Residues. International Journal of Sustainable Built Environment, 4, 165-188. https://doi.org/10.1016/j.ijsbe.2015.11.002

[2] Lee, U., Han, J. and Wang, M. (2017) Evaluation of Landfill Gas Emissions from Municipal Solid Waste Landfills for the Life-Cycle Analysis of Waste-to-Energy Pathways. Journal of Cleaner Production, 166, 335-342. https://doi.org/10.1016/j.jclepro.2017.08.016

[3] Mohareb, E.A., MacLean, H.L. and Kennedy, C.A. (2011) Greenhouse Gas Emissions from Waste Management-Assessment of Quantification Methods. Journal of the Air \& Waste Management Association, 61, 480-493.

https://doi.org/10.3155/1047-3289.61.5.480

[4] Sadeghi, S., Shahmoradi, B. and Maleki, A. (2015) Estimating Methane Gas Generation Rate from Sanandaj City Landfill Using LANDGEM Software. Research Journal of Environmental Sciences, 9, 280. https://doi.org/10.3923/rjes.2015.280.288

[5] US EPA (2005) Landfill Gas Emissions Model (LandGem) Version 3.02 User's Guide. United States Environmental Protection Agency, EPA-600/R-05/047. http://www.epa.gov/ttncatc1/dir1/landgem-v302-guide.pdf

[6] Cyril, K.M., Essi, K., Agboue, A. and Albert, T. (2018) Characterization of the Parameters and Estimation of Potential Biogas of A Landfill in Tropical Area: Case Study of the Principal Landfill of Abidjan Akouedo Landfill. Research \& Reviews: Journal of Ecology and Environmental Sciences, 6, 43-49.

[7] CLIMATE-DATA.ORG. https://en.climate-data.org

[8] National Institute of Statistics (Côte d'Ivoire) (2018) Côte d'Ivoire Population and Housing Census 2014. http://www.ins.ci/n/

[9] https://news.abidjan.net/h/634005.html

[10] Kumar, A. and Sharma, M.P. (2014) Estimation of GHG Emission and Energy Recovery Potential from MSW Landfill Sites. Sustainable Energy Technologies and Assessments, 5, 50-61. https://doi.org/10.1016/j.seta.2013.11.004

[11] Kalantarifard, A. and Yang, G.S. (2012) Estimation of Methane Production by LANDGEM Simulation Model from Tanjung Langsat Municipal Solid Waste Landfill, Malaysia. International Journal of Science and Technology, 1, 481-487.

[12] Ayodele, T.R., Ogunjuyigbe, A.S.O. and Alao, M.A. (2017) Life Cycle Assessment of Waste-to-Energy (WtE) Technologies for Electricity Generation Using Municipal Solid Waste in Nigeria. Applied Energy, 201, 200-218. https://doi.org/10.1016/j.apenergy.2017.05.097

[13] Park, J.-K., Chong, Y.-G., Tameda, K. and Lee, N.-H. (2018) Methods for Determining the Methane Generation Potential and Methane Generation Rate Constant for the FOD Model: A Review. Waste Management \& Research, 36, 200-220. https://doi.org/10.1177/0734242X17753532 
[14] Rezaee, R. (2014) Estimation of Gas Emission Released from a Municipal Solid Waste Landfill Site through a Modeling Approach: A Case Study, Sanandaj, Iran. Journal of Advances in Environmental Health Research, 2, 13-21.

[15] Scarlat, N., Motola, V., Dallemand, J.F., Monforti-Ferrario, F. and Mofor, L. (2015) Evaluation of Energy Potential of Municipal Solid Waste from African Urban Areas. Renewable and Sustainable Energy Reviews, 50, 1269-1286. https://doi.org/10.1016/j.rser.2015.05.067

[16] Tsatsarelis, T. and Karagiannidis, A. (2009) Estimation of Future Methane Production from Hellenic Landfills. Global NEST Journal, 11, 162-171.

[17] Saer, A., Lansing, S., Davitt, N.H. and Graves, R.E. (2013) Life Cycle Assessment of a Food Waste Composting System: Environmental Impact Hotspots. Journal of Cleaner Production, 52, 234-244. https://doi.org/10.1016/j.jclepro.2013.03.022 